AUTHORSI

R.-D. Penzhorn, Kernfurschungszencrum Karlsruhe, Gerniany

J. L. Anderson, Tritiun Science \& Technology Group Materials Science Technology Division

R. Haange, JET Joint Undertakıng, England

B. Hircq, Atomic Energy Comentssion, France

A. Meikle, Canadian Fusion, Canada

Y. Naruse, Japan Atomic Energy Research Institute, Japan

SUBMITTED TO

Second International Symposium on Tusion Nuclear lecnnolongy Karlsruhe, Gerillany

June $2-7,1991$

IDSCI.AIMR'R

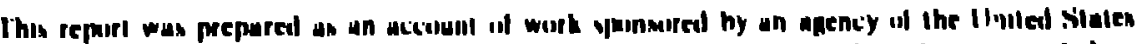

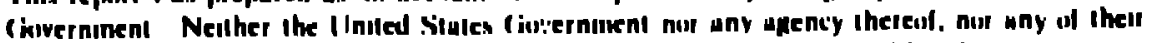

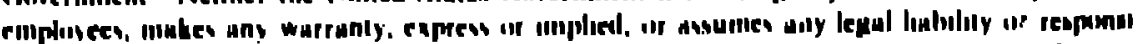

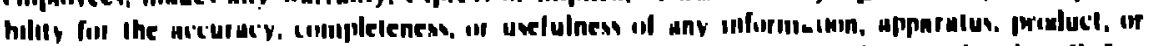

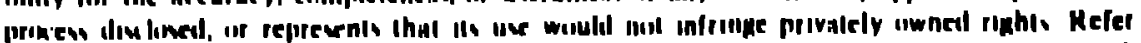

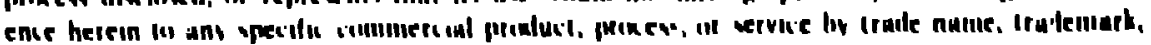

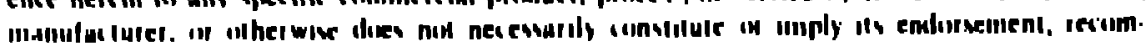

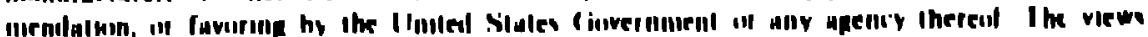

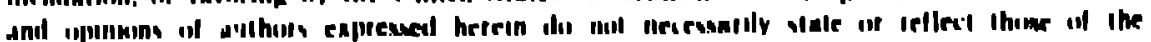

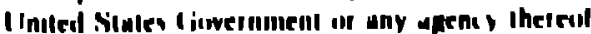




\title{
TECHNOLOGY AND COMPONENT DEVELOPMENT FOR A CLOSED TRITIUM CYCLE
}

\begin{abstract}
R.-D. Penzhorn ${ }^{1}$, J. Anderson ${ }^{2}$, R. Haange ${ }^{3}$, B. Hircq ${ }^{4}$, A. Meikle ${ }^{5}$, Y. Naruse ${ }^{6}$,
${ }^{1}$ Kerntorschungszentrum Karlsruhe, Institut für Radiochemie/Tritium Laboratorium Karlsruhe, Postfach 3640, 7500 Karlsruhe, Germany; ${ }^{2}$ Tritium Systems Test Assembly, L.os Alamos National Laboratory, Los Alamos, 87545 New Mexico, U.S.A.; ${ }^{3}$ JET Joint Undertaking, Abingdon, Oxfordshire OX14 3EA, United Kingdom; ${ }^{4}$ Atomic Energy Commission, Centre d'Etudes de Bruyères-le-Chatel, 91680 Bruyères-le-Châtel, France; 5 Canadian Fusion Fuels Technology Project, Mississauga, Ontario, LSJ IK3 Canada; ${ }^{6}$ Japan Atomic Energy Research Institute, Tritium Engineering Laboratoly, Tokai-mura, Iloaraki-ken 319-11, Japan
\end{abstract}

\section{Abstract}

A brief sum the most important subsystems of the fuel cycie of a fusion reictor, i.e. the plastiat exhenst pumping system, the exhaust gas clean up system, the isotope separation, thre Iritium storage and the tritium extraction from a blanket is provided. lixperimental results, single componemt developments, and technical tests including those with relevalnt anounts of tritiun that constitute the bassis of proposed integral process concepts are described.

\section{Introduction}

It is of crucial importance for the altaiment of tritum self-sufficicncy in a linsion

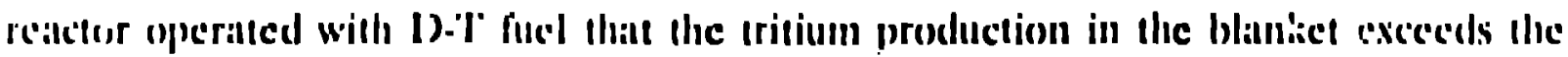
late of tritium burning in the plissma by at least the anoune of tritium less by' ratliostctise

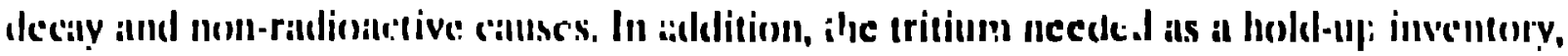

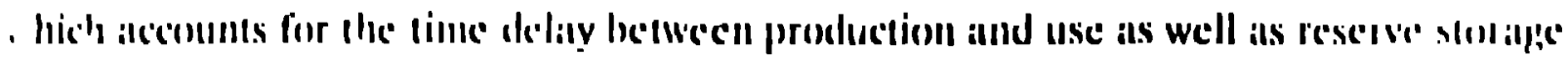

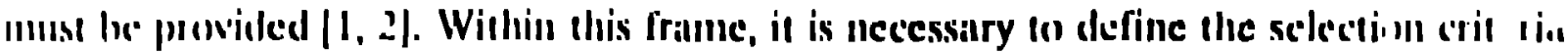
for desig̣n comecpts and the tange of acceptable performante parameters of all tritum 
processing systems, which comprise the plasma exhaust gas pumping system, the exhaust gas clean up system, the isotope separation, the tritium storage, and the tritium extraction. from the blanket. For tritium self-sufficiency it is important that nonradioactive tritium losses - for instance by permeation through structural materials into coulants - be minimized, and that the mean residence time of tritium in tritium processing systems as well as the probability of failure and down-time to repair tritium processing units be kept as low as possible. Furthermore, it must be shown that tritium technology once developed and proven can be applied safely, reliably, and economically. Based on these judgments, strong fusion technology related research and development activities, increasingly using substantial amounts of tritium, are under way in Canada, tine European Community, Japan, the LI.S.A., and the LISSR. In addition, much relcvant experience will be gained at a large facility in Darlington, in which 2500 grams of tritium have been removed from heavy water in a period of continuous operation that started June 1990 .

Because of the large increase in the number of relevant publications and the numerous new activities initiated in recent years, only some of the most recent developments in the field of tritium technology concerning a closed fuel cycle will be di cussed in this paper. An attempt, however, will be made to cover all major and advanced experimental facilities designed for demonstration with tritium of components and processes that are comm::encing design, are under construction, or have already been used in a test progran.

\section{Plasma exhaust gas pumping}

\subsection{Process reyuircments}

The plasma valcumm pumpling system includes a primary vacuum system and a backing system. It evacialtes the torus during all operational and maintenince phases and (lelivers the resulting gas stream to the fuel processing system at a pressure near almopplacric. The system must provide evacuation under conditions of burn and dweli, pump-down and conditioning. los sattisfy all the multiple functional repuirements the

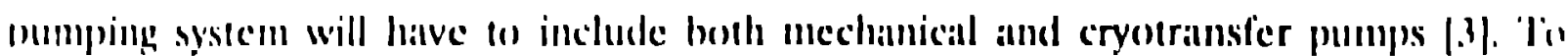

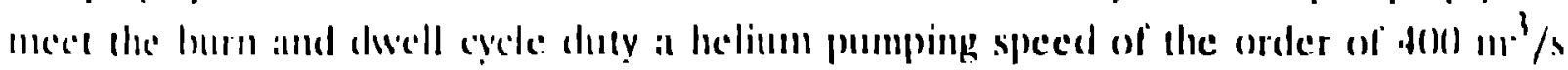
(such as repunited lor lhe International Thermonuclear lixperimental Reatelor llT:R)

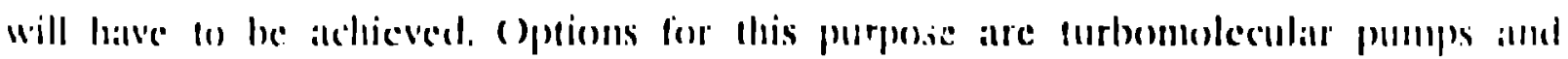


compound crjopumps together with regeneration pumps. For compound cryopumps two variants are under discussion, i.e. cryotrapping of helium by an argon spray technique or crjosorprion of helium on activated charcoal. Advanced pumping systems, which offer a substantial potential saving in equipment are also being considered [4] but due to lack of sufficient test data, these systems will not te discussed in this paper. The pumps of the mechanical train must be available not only for the initial stages of pump-down from atmospheric pressure but also to back the turbomolecular pumps during torus conditioning and the later stages of pump-down. The installed capacity of the mechanical system is largely determined by the helium glow discharge duty.

\subsection{Component development}

\subsubsection{Large roughing pumps}

Large mechanical oil-tree scroll pumps are proposed to pump air, helium, argon, hydrogen isotopes, etc., with and without impurities, in a number of subsystems such as plasma exhaust pumping, fuel clean-up, tritium extraction from the blanket, isotope separation, waste treatment, etc.

Since only little information was available on the performance of NORMETIXX scroll pumps with fusion fucl relevant gusses, pumps with nominal pumping speeds for nitrogen of $15,18,60$ and $1.50 \mathrm{~m}^{3} / \mathrm{h}$ were tested either with the pure gasses $\mathrm{N}_{2}$, air, $\mathrm{Ne}$, $A{ }_{1},\left(.1 I_{.2}, C_{. j} I_{8}, I l e, D_{2}\right.$, and $H_{2}$ or their mixtures [5]. The data obtained revealed thit where:s air and argon are pumped with the nominal efficiency, other giasses show pumping efficiencies decreasing in the order Ile, deuterium, methane and hydroges. To investigate the effect of suction pressure (0.1 - 1000 mbar) on througliput $\left(1-10^{4}\right.$

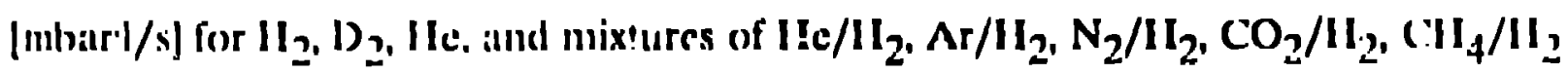
several pump combinalions (including a netal bellows pump) were used. lirom the dala obtained with all the tested scroll pumps it was concluded that for the gasses $\mathrm{Il}_{2}, \mathrm{I}_{2}$, (' $!_{4}$, and Ile an exhaust pressure of less than $4(x)$ mbar is necded to achieve the pumping speeds specified for nitrogen. The pumping speed curves specified for the o() and the $1.50 \mathrm{~m}^{3} / \mathrm{h}$ pumps for nitrogen could also be altained with $\mathrm{H}_{2}$, when this gats

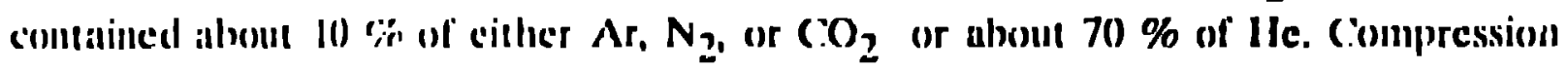
ratios for nitrugen, leclimm, methane, deuterium, and hydrogen were measured for all of

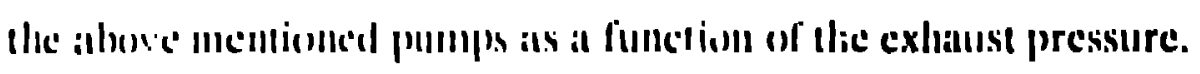

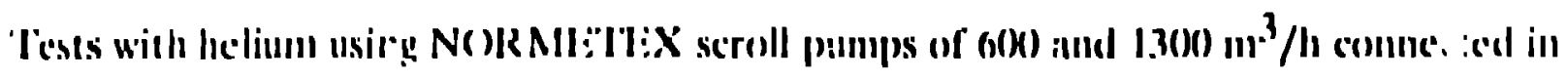


series have also been carried out at the Kernforschungszentrum Karlsruhe (KfK) [6]. Results on the throughput of this pump combination as a function of suction pressures down to $10^{-2}$ mbar were obtained.

A large oil-free, reciprocating, water cooled, single acting, four stage vertical piston pump has been c'eveloped for high level tritium service in Japan [7]. At suction pressures above 13 mbar pumping speeds of approx. $180 \mathrm{~m}^{3} / \mathrm{h}$ were acinieved with $\mathrm{H}_{2}$, $\mathrm{D}_{2}$, He and $\mathrm{N}_{2}$. At lower suction press..res the pumping speed dropped drastically. The ultimate pressure for $\mathrm{N}_{2}$ was slightly below 1,3 mbar and that for $\mathrm{H}_{2}$ was 2.6 mbar. The loss of compression is believed to be caused by backflow of gas through the piston. A reciprocating, tritiuna compatible pump operated at 1000 mbar discharge pressure was tested in conbination with an oil-free magnetic levitated turbomolecular pump at the Tritium Engineering Laboratory (TEL). With this combination it was observed that only $\mathrm{N}_{2}$ is pumped down to $1.3 \cdot 10^{-4}$ mbar at pumping speeds of ca. $1080 \mathrm{~m}^{3} / \mathrm{h}$. The maximum pumping speed observed for $\mathrm{He}$ and $D_{2}$ was approx. $360 \mathrm{~m}^{3} / \mathrm{h}$ at around $1.3 \cdot 10^{-2}$ mbar. The minimum hydroge 7 pressure achieved with this pump was approximately 1.3 mbar.

The function of the mechanical forevacuum system at JET is to provide the capability to pump down the torus, the neutral injector boxes or pellet injector boxes and thereafter back up the turbonolecular punps [8]. Relevant information will be obtained from a corresponding mechanical furevacuum system, composed of one $600 \mathrm{~m}^{3} / \mathrm{h}$ and two 15i) $\mathrm{m}^{3} / \mathrm{h}$ ciry NORMETEX scroll pumps presently being installed in Culham. To cope with possible water inleaks into the torus or into the neutral injector box, at water condensor op rated at $5^{\circ} \mathrm{C}$. has been installed upstream and downstrentm of the mechatrical pumps.

\subsection{2. ('ryosorption and cryotransfer pumps}

firom experiments it the Tritium Systems 'Test Assembly ('TSI'A) with leclium/deuterium mixtures pumped with a single charcost activated pancl $k e p t$ il $4 k$ it wiss ohserved that the calpacity for helium is reduced from $1.8 \mathrm{mbar} / / \mathrm{cm}^{2}$ (1) 10.9 mbart//m², when the amount of deuterium in the pumped mixture is increased from 0

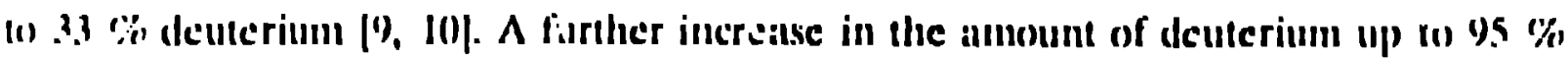

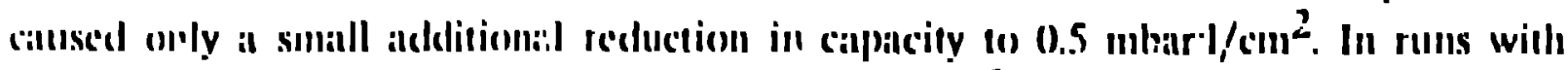

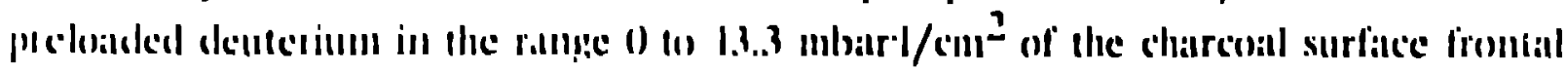

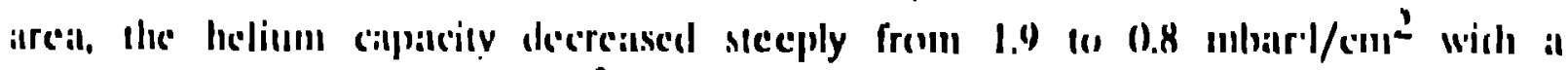

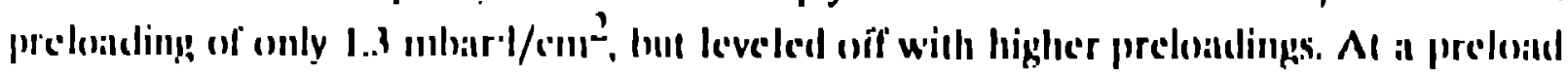


of $13 \mathrm{mbar} \cdot 1 / \mathrm{cm}^{2}$ the helium pumping speed decreased to $75 \%$ of thit oblained in the relerence case without deuterium. It was concluded, that charcoal has a high capacity and speed for helium and requires only minimal bakeout procedures.

For screening test purposes more than 300 combinations of various sorption materials and binders were subjected at $\mathrm{KfK}$ to temperature cycles in the range $323 / 573 \mathrm{~K}-\mathrm{IN}_{2}$. Measurements on the pumping speed and scrption capacity of selected ac'sorption panels with $\emptyset=50 \mathrm{~mm}$ at $4.2 \mathrm{~K}$ yiclded specific helium pumping speeds, $S$, in the range $5 \cdot 10^{-6}<\mathrm{S}<2.3 \cdot 10^{-1} \mathrm{l} / \mathrm{s}^{\cdot} \mathrm{cm}^{2}$ measured with a double baffle at feed rates of $\mathrm{Q}>10^{-4}$ mbarl/s and $p-10^{-4} \mathrm{mbar}$ [11]. In general, activated chaicoal showed better properties than zeolite $5 \AA$. In a facility with cryopanels of $\varnothing=4(10 \mathrm{~mm}$ the sorption characteristics of activated charcoal was examined with helium and helium containing several impurities at throughputs in the range $0.084-8.44 \mathrm{mbar} \cdot \mathrm{l} / \mathrm{s}$.

Ciyotranster pumps will be used to collect gases like hydrogen and impurities from a helium carrier gals at JET [8]. By careful temperature control during warm-up pure hydrogen gas will be distilled off directly into the isotope separation system. Residual impurities will be transfered in a second process step into ar: impurity processing system. The cryotransler pump at JET is operated at about $4 \mathrm{~K}$. Impurities are released by cycling to room temperature and occasionally to approximately $470 \mathrm{~K}$.

\subsubsection{Turbomolecular pumps}

人 25 (1)(0) $1 / \mathrm{s}$ single turbomolecular pump rlesigned for an ultimate valcuun of $10^{-7}$ Pa is: urider development in Japan and scheduled for tests in late 1991 [12].

\section{Ilisimin cxhaust hals cleill-ulp}

\section{I. Processes recpuirements}

The fucl processing system removes the inpurities from the "unburned" find during burn and dwell in concentrations luwer than 1 ppm and recovers tritium from wiste falses

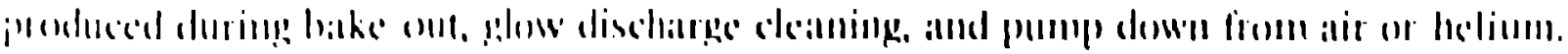

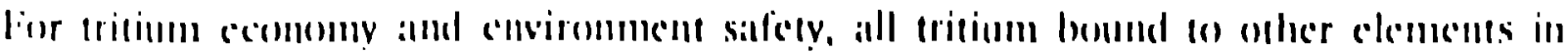

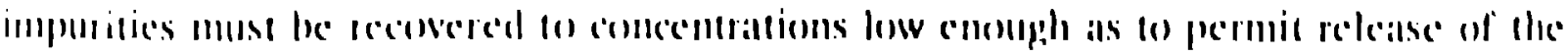


produced waste gas via a tritium waste treatment system [3].

Total flow rates for NET II are estimated to $74 \mathrm{~mol} / \mathrm{h}(69 \mathrm{~mol} / \mathrm{h}$ hydrogen isotopes) Juring burn \& dwell and $16 \mathrm{~mol} / \mathrm{h}$ ( $1 \%$ impurities) or $50 \mathrm{~mol} / \mathrm{h}$ (0.1\% impuritics during glow discharge cleaning with deuterium or helium, respectively. Flooding of the reactor with helium will be necessary about once a week. When accidental pressurization of the reactor occurs, the gas composition will be air with a concentration of water determined by the prevailing humidity, which will be contaminated with tritium desorbed from the reactor wall. The total quantity of gas to be pumped off in either case will be of the order of $100 \mathrm{kmol}$. The total tritium inventory of this subsystem (as of all other subsystems) shall be minimized (for ITER the max. limit is $200 \mathrm{~g}$ ). The tritium content of all gaseous, liquid and solid impurity streams leaving the plasma clean up system shall also be reduced to a minimum.

\subsection{Component development}

\subsubsection{Permeators}

Palladium/silver alloy permeators separate specifically hydrogen isotopes from the fuel ash helium and from hydrogenated as svell as non-hydrogenated impurities. Permeators are selected hecause they are widely used on industrial scale, deliver a hydrogen product stream of very high purity (99.9990\%), operate with very low tritium inventory, and produce no process waste. Gases such as $\mathrm{N}_{2}, \mathrm{CO}$ (partial pressure up to 1 bar), $\left(\mathrm{C}_{2}\right.$, $\left(H_{4}, \mathrm{NII}_{3}\right.$, and $\mathrm{II}_{2} \mathrm{O}$ (partial pressurs up to $200 \mathrm{mbar}$ ) do not influence the tate of hydrogen permeation at temperatures above $3000^{\circ} \mathrm{C}$ [13].

At the Tritium linginering laboratory a palladium/silver permeator of 48 permeation lubes has been tested suceesfully at $57.3 \mathrm{~K}$ at a feed pressure of 1 bar and a permeate pressure of 1.3 mbar, indicating that more than $98 \%$ of the hydrogen isotopes fod into the difuser permeated (1) produce a pure product stream. The nydrogen feed rate was varied between 0.5 and 2 l/min, the bleed flow rate was 0.3 l/min. Several .3 - 5 dily runs with I g of tritium were perlormed since early 1988 [14].

I:xperiments with a palladium/silver permeator having a total permeation alrea of approx. (1.14 $\mathrm{m}^{2}$ have been rarricd ont al $57.3 \mathrm{~K}$ with hydrogen/helium mixtures all

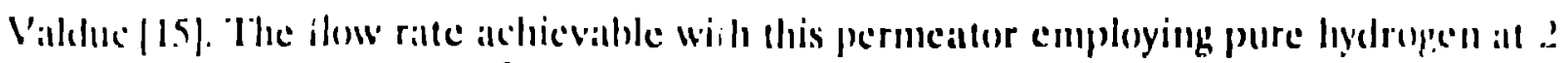

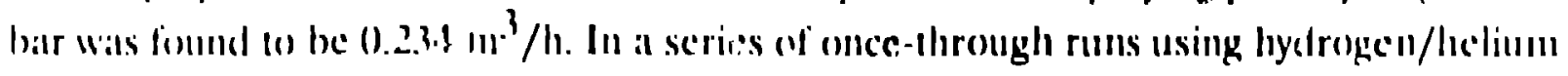
g:as mixtures drawn with a pump from a reservoir and compressed into the permeallor, 
the partial pressure of hydrogen served as the diving force. During the operation of the permeator a fraction of the gas from the feed side was continuously removed via a flow rate controller. The results provided information on the balance between the permeation rate (influenced by the blanketing effect) and the percentage of hydrogen carried over with the impurities. Following these tests with hydrogen/helium mixtures, a tritium compatible permeator of 1/5 NET scale has been designed and built.

A modified commercial palladium/silver permeator of $1 / 8 \mathrm{NET}$ scale $\left(0.12 \mathrm{~m}^{2}\right.$ effective permeation area), which has been constructer iur work with tritium will be tested at the Tritium Laboratory Karlsruhe (TLK) in early 1992 for a period of at least one year, using gas mixtures that simulate the plasma exhaust [16]. Design improvement of the permeator is the result of extensive permeator cold tests in combination with a 150 $\mathrm{m}^{3} / \mathrm{h}$ scroll pump and a Metal Bellows pump as well as detailed modeling calculations. The objectives of the experiment arc a) to study the effect of decay helium in the membrane on the permeation rate of hydrogen isotopes through palladium/silver and its mechanical integrity and b) to evaluate the long-term resistance of the permeator towards possible poisoning by impurities in the gas mixture. The performance of in-line infrared spectrophotometers, designed for the continuous detection of $\mathrm{CO}, \mathrm{CO}_{2}$, and $\mathrm{CH}_{4}$ or for the continuous long-term specific analysis of $\mathrm{CO}$ (detection limit < $10 \mathrm{ppm}$ ) will be examined in view of the development of process control in tritium conducing systems.

\subsubsection{Electrolysis cells}

Substantial progress has been achicved in recent years in the development of tritium compatible electrolysis cells. These cells may become crucial components of the plasma exhaust cleanup system or the tritium extraction system from a reactor blanket.

Several ceramic electrolysis cells that operate at elevated temperature with water vapour have heen designed, manufactured and tested by JAERI scientists. The cell presenty installed in a lo(p) at IST $A$ contains ten sintered stabilized zirconia tubes with calcined platinum electrodes at the inside and outside surfices [14]. Water vapour in the feed gis is decompused at the inner surface of the electrode to form hydrogen/tritium. pure oxygen evolves from the outer electrode surface. From measurenents on the comersion ratio al: a function of the electrochemical potential across the cell a ansersion efficiency luwer than expected was observed. Special aflention was forensed on the clectrolysis of impurities such a: ( ()$^{2}$ and $\mathrm{CO}_{2}$. At the potential at which the cell

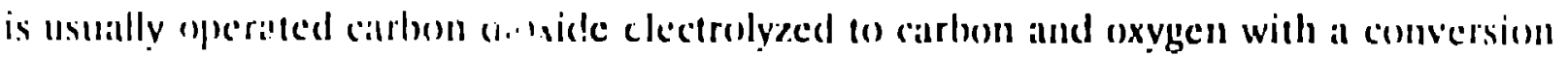


ui only $3 \%$. The electrolysis of water on the other hand is not influenced by the presence of this gas. Long-term tests at $913 \mathrm{~K}$ with $\mathrm{T}_{2} \mathrm{O} / \mathrm{CO}_{2} / \mathrm{N}_{2}$ at a carrier throughput of $0.4-1.0 \mathrm{l} / \mathrm{min}$ have been carried out succesfully.

An electrolysis cell with a hollow palladium/silver cathode coated with porous palladium black has been developed at Valduc and tested successfully with tritium with up to $1.2 \times 10^{13} \mathrm{~Bq} / \mathrm{ml}$ of water [17]. The cell uses $\mathrm{NaOH}$ as electrolyte and is operated at $353 \mathrm{~K}$. Experiments with $3.7 \times 10^{13} \mathrm{~Bq}$ tritium per $\mathrm{ml}$ water are forseen in 1991.

A low inventory capillary electrolyzer (ALICE) for the recovery of tritium from tritiated water with up to $3.7 \times 10^{13} \mathrm{~Bq} / \mathrm{ml}$ has been developed by SKC/CEN at $\mathrm{Mol}$ in Belgium [18]. Sulfuric acid has been chosen as electrolyte, thermoelectric heat pumps cool the cell to $281 \mathrm{~K}$. With a prototype cell up to 3000 hcurs of continuous operation have been accumulated. Because of the high radiotoxicity of tritium and the need to work at constant tritium inventory a closed loop has been built that allows recombination of the electoolytically produced gases and their recirculation into the cell. To test and demonstrate the performance of the cell two experiments, each with a duration of 1000 h, will be carried out at Chalk River Laboratories in 1991.

\subsubsection{Getter beds}

Metal getters react with hydrogen isotopes containing impurities at elevated temperatures to give stable products and recoverable hydrogen.

(ielter beds containing uranium metal powder or iron metal powder have been developed at .IFT to recover hydrogen isotopes from tritiated water by reacting to metal oxide and uranium hydride [19]. The beds are heated by two independent heating coils (1) operate between 29() and approximately $770 \mathrm{~K}$ (design temperature $770 \mathrm{~K}$ ) and cooled by a separaic gas cooling loop. The beds have sintered inconel tubular filters at the inlet and outlet (o) prevent dust migration, and are housed within an intermediate container to minimize leat and permeatled tritium losses.

A gelter bed containing $1.5 \mathrm{~kg}$ of uraniun powder has been demonstrated for the recovery of tritium from IIT) released during the thermal reactivation of molecular sicves [2()]. For the investigation of the reaction of uranium with other tritiated impurities a uranium powder bed of 200$) \mathrm{g}$ designed for a max. temperature of 0.50 "( wals comployed. Scries of tests with $\Pi_{2} / \mathrm{CH}_{4}, H_{2} / \mathrm{NO}$, and $\Pi_{2} / \mathrm{NO} / \mathrm{Cl}_{4}$ all several cemperattures up $60878 \mathrm{~K}$ give evidence that a high degree of purification at! he 
achieved with uranium at temperatures higher than $973 \mathrm{~K} . \mathrm{Q}_{2} / \mathrm{NO}$ and $\mathrm{Q}_{2} / \mathrm{NH}_{3}(\mathrm{Q}$ jenoting $H, D, T$ ) as well as more complex mixtures containing in addition some carbon oxides were found to undergo radiolytical reactions within hours leading to changes of the original chemical compositior. Experiments in another reactor at $963 \mathrm{~K}$ demonstrated that with inlet concentrations of methane in hydrogen in the range 2.3 2.7 vol. \% outlet concentrations lower than 0.26 vol. \% can be achieved in a oncethrough modus. The detailed design of a new high temperature getter bed is under way.

After successful tests with gas mixtures simulating TLK impurity streams employing three getters beds operated at $773 \mathrm{~K}$ (retention of oxygen and oxygenated compounds), at $973 \mathrm{~K}$ (retention of nitrogen and ammonia) and at $1173 \mathrm{~K}$ (retention of hydrocarbons) in series a Clean-up System for the TLK was developed [21]. For the second and third getter stage of the system now under constuction alumina ceramic vessels are used to contain the uranium.

The applicability of two commercial gas purifiers in series for the removal of carbon oxides, exygen, and water at about $523 \mathrm{~K}$ and of nitrogen and hydrocarbons at temperatures above $673 \mathrm{~K}$ from a helium/hydrogen isotopes stream is under investigation in a technical facility to be operated with tritium [22].

\subsubsection{Adsorber beds}

In 'TSTA a bed with $1.6 \mathrm{~kg}$ of $5 \mathrm{~A}$ molecular sieve at $77 \mathrm{~K}$ was used to remove impurities from a hydrogen gas stream containing $1 \%$ impurities (90\% nitrogen and $10 \%$ methane) [23]. The concentration of both impurities could be reduced to levels below the analytical detection limits. The average quantity of impurity adsorbed was $100.8 \mathrm{l} / \mathrm{kg}$ molecular sieve, corresponding to $84 \%$ of the theoretical capacity.

Adsurption studies with deuterium/impurity mixtures are in progress at Bruyères-le(.hâtcl, enploying a cryotrap that contains $128 \mathrm{~g}$ of type 5A zeolite activated at $498-573$ $K$ (1) it residual watter content of $3 \%$ by weight [20]. Impurities such as $\mathrm{N}_{2}, \mathrm{O}_{2},\left(\mathrm{D}_{4}\right.$, $\mathrm{CO}_{\mathrm{x}}$ and $\mathrm{Ar}$ are removed from deuterium carrier gas to levels below $10 \mathrm{vpm}$ at temperatures below $113 \mathrm{~K}$. Tiable I shows the effect of temperature on the cotrapping of deuterium in the molecular sieve. lividently, at emperatures at which efficicnt removil of $\mathrm{CD}_{4}, \mathrm{~N}_{2}, \mathrm{O}_{2}$, and $\mathrm{Ar}$ from deuterium is achieved, i.e.: $<113 \mathrm{~K}$, the cotrapped deuterium inventory becomes substantial. The residual water in the zeolite undergoes a slow exchange reaction with DT and $\mathrm{T}_{2}$. The exchange rate constant was found to be directly proportional to the concentration of tritium. 
Table I Cryotrapping of $\mathrm{D}_{2}$ and impurities on zeolite $5 \mathrm{~A}$

\begin{tabular}{lll} 
Temperature & \multicolumn{2}{c}{ cryotrapping } \\
$\mathrm{K}$ & $\begin{array}{c}\text { deuterium }+ \text { impurities } \\
. \mathrm{Jl}(\mathrm{STP}) / \mathrm{g}\end{array}$ & $\begin{array}{l}\text { deuterium } \\
\mathrm{ml}(\mathrm{STP}) / \mathrm{g}\end{array}$ \\
\hline & & \\
153 & 32.8 & 9.2 \\
133 & 35.4 & 11.8 \\
113 & 43.1 & 19.9 \\
103 & 58.5 & 34.9 \\
93 & 82.5 & 59.5 \\
\hline
\end{tabular}

At KFK the adsorption in zeolite $5 \mathrm{~A}$ of hydrogen isotopes from mixtures with helium is under investigation at temperatures down to $53 \mathrm{~K}$ employing a cryostat integrated into a tritium compatible loop. The residual water in the zeolite can be reduced to levels below $0.5 \%$ by weight without removal of the adsorption cell by heating the cell up to $723 \mathrm{~K}$ under vacuum [24].

\subsubsection{Combined permeator-catalysis reactor}

Catalytic reactions based on the establishment of thermodynamic equilibrium with formation of hydrogen isotopes as one of the products, i.e.

$$
\begin{gathered}
\mathrm{CH}_{4}=\mathrm{C}+2 \mathrm{H}_{2} \text { or } \\
\mathrm{CO}+\mathrm{H}_{2} \mathrm{O}=\mathrm{CO}_{2}+\mathrm{H}_{2}
\end{gathered}
$$

could be intluenced rith a shift of the equilibrium towards the products (quantitative conversion) by combination of the catalytic reactor with a meml rane selectivily permeable for hydrogen. Experimental work for an evaluation of this option is being pursued at TSTA and in Karlsruhe. 


\subsection{Integral process concepts}

In the following some of the integral process concepts under discussion or test will be briefly described.

\subsubsection{Catalysis/permeator}

For the processing of the primary exhaust gases of a fusion reactor during burn $\&$ dwell, glow discharge cleaning, bake out, and pump down (air or helium) a concept based on catalytic reactions combined with palladium/silver permeators has been proposed and an engineering design for NET II carried out [25].

The plasma exhaust gases from burn \& dwell, c helium/c..sutcrium glow discharge are first fed into a permeator of approx. $1 \mathrm{~m}^{2}$ total neation area where $99.85 \%$ of the hydrogen isotopes are extracted by pumping the secondary side of the permeator with a $600 \mathrm{~m}^{3} / \mathrm{h}$ scroll pump backed up by an oil-fr_e metal bellows booster pump. Because the separated hydrogen isotopes are of high purity they can be fed directly into the isotope separation system. The effluent stream from the pe. meator, containing tritiated impurities (mainly hydrocarbons, residual hydrogen isotopes, and water) and nontritiated impurities (noble gases, carbon oxides, nitrogen) are collected in a tank and processed in a semi batch way in two subsequent catalytic reaction steps: a) on a nickel citalyst at $773 \mathrm{~K}$ hydrocarbons and ammonia are decomposed into the elements up to thermodynamic equilibrium and b) on a copper chromite catalyst at about $473 \mathrm{~K}$ tritium containing water is converted by reaction with carbon monoxide into molecular hydrogen isotopes and carbon dioxide via the "water gas shift" reaction. The hydrogen isotopes liberated from these catalytic reactions are extracted with a second pernicator integraled into the catalytic loop. To achicve a high degree of tritium recovery (and decomtanination) the second permeator is inacked up by a turbomnlecular pump. 1)epending upon the partial pressure of water carbon dioxide may be added to the gias stream. This gas reacts with the carbon deposit on the nickel catalyst to procluce the carbon monoxide needed for the water gas shift reaction, while at the same time increasing the life-time of the cattalyst.

Pump down exhaust gass from torus flooding with helium or from air break-in is palssed over a recombiner to oxidize molecular hydrogen isotopes and hydrocarbons into witter and carbon dioxide (when the process giss is helium oxygen needs to be added). Watter is first ret:ined in a cryotrap) and then volatilized with carbon monoxide as the catrrier gits. The resulting galseous mixture is passed through a copper chromite bed where the willer 
is converted into hydrogen. The hydrogen is extracted by permeation and the bleed gas is sent once-through via the impuity processing loop into the tritium waste system for ultimate detritiation.

Every single step of this process has been studied in the laboratory. The kinetics and reaction mechanism of the catalytic decomposition of methane, ethylene, acetylene and other higher hydrocarbons has been studied in detail. Integral tests with relevant amounts of tritium have been carried out at TSTA [26]. The water gas shift reaction with $\mathrm{CO}$ as carrier gas has been demonstrated in a technical scale (attained conversion: $1.5 \mathrm{I}$ of liquid water per day). A contract has been awarded to industry for the design, manufacture, assembly and commissioning of an experimental facility having $1 / 8$ NET II scale to be installed in the TLK for the deinonstration of the process.

\subsubsection{Molecular sieves/palladium membrane reactor [23]}

After the separation of the "unburned" DT fuel, the remaining impurity stream sontaining a small fraction of DT is first routed through a noble metal calalyst bed at $450 \mathrm{~K}$ in which oxygen is reduced into water. The hot gas leaving the recombiner is then cooled to room temperature before being passed through a molecular sieve bed kept at rom temperature. In this bed water and ammonia are retained. Downstream the process gas passes through another molecular sieve bed cooled to $77 \mathrm{~K}$, in which all other impurities, i.e. $\mathrm{N}_{2}, \mathrm{CH}_{4}$, and $\mathrm{CO}$, but no He are trapped. To minimize DT cotrapping, the $1 \mathrm{~N}_{2}$ cooled molecular sieve bed is preloaded with hydrogen (the impurities will displace the hydrogen and load completely the hed). To smooth the process three trains of molecular sieve heds will be ueed: one in operation. one in regeneration and one in stand by. The cilluent gas from the molecular sieve beds is send (1) the cryogenic isotope separation system after passing ihrough a last guard bed.

Tin process the impurities and some cosorbed DT, the room lemperature and the I $\mathrm{N}_{2}$ cooled beds are regenerated at $023 \mathrm{~K}$ and $4(0) \mathrm{K}$, respectively and the releatsed giass direced on a palladium membrane reactor containing suitatle catalysts. Iydrogen isofopes liberated in the reactor from a) the decompissition of hydrocarbons, b) the Wal. $r$ gas shift reaction and e) the decomposition of ammonia (sec 3.2.0.) are direcily extracted by permeation and sent to the isotope separation system. Due to the contunuous removal of lydedrogen all chemical equilibria are shifed in the favourable direction. As a result very hịh conversions are achieved. 


\subsubsection{Hitex process}

Recently a novel process concept for recovering tritium from the impurities in the fusion reactor exhaust stream has been proposed [27]. After the removal of the bulk of the "unburned" D,T in a first permeator, a batch of the impurity gases (tritiated and untritiated) with some D,T carry-over is collected in a previously evacuated vessel up to a preset pressure and then swamped with protium up to a pressure of $100 \mathrm{kPa}$. The resulting gas mixture is circulated trough a high temperature exchange (HITEX) reactor where isotopic equilibration between hydrogen and the impurity molecules takes place. The reactor consists of a horizontal tube with an axially coiled Pt hot wire operated at a temperature in the range $700-1100 \mathrm{~K}$, depending cut the amount of methane present. The hot wire is prevented from coming into contact with the wall of the reactor by suitably positioned spacers. To minimize tritium perneation, the walls are cooled to 350 $\mathrm{K}$ with a water jacket. The average temperatur 2 of the reactor is estimated to be $500 \mathrm{~K}$. Tritiated hydrogen is extracted from the loop with the palladium/silver permeator $\mathrm{S} 1$. To compensate for the extracted hydrogen isotopes hydrogen is fed into the loop until the quantity added is equivalent to 20 volume changes of the buffer vessel. In this way the initial tritium content is reduced by a factor of the order of $10^{-9}$ and cain be discharged into a conventional datritiation system.

Since the size of the isotope separation is determined by the waste water detritiation stream and the pellet injector propellant clean-up stream, the impact of the IIIT: $X$ hydrogen isotope stream aippears to be comparatively small.

\section{i.3.t. Permeation/oxydattion/electrolysis}

liwo concepts based on the combination of permeation, impurity oxidation and clectrolysis as main process steps have developed.

At JAI:RI a fuel clean-up syinem was buile that has been used with up (1) $1 \mathrm{~g}$ of tritium $|28|$. The first component is a precious metal diffuser to extract pure hydrogen isofopes from the process stream. The bleed gats from the diffuser is then routed through a altalytic reaclor in which all impuritices are oxidized lo yickl tritialcel waller. ()xygen eceured for the oxidation of the tritialted species is supplied by an clectrolysis cell or form external sources. The exhaust gats from the caltalytic reactor is patssed through a

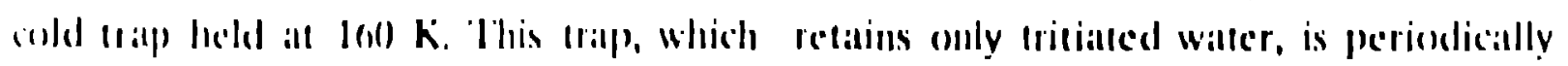

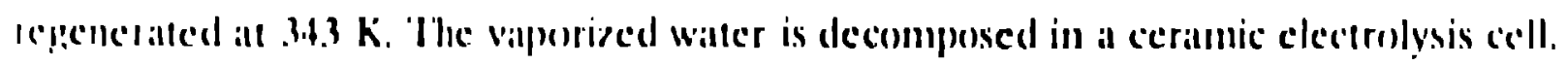

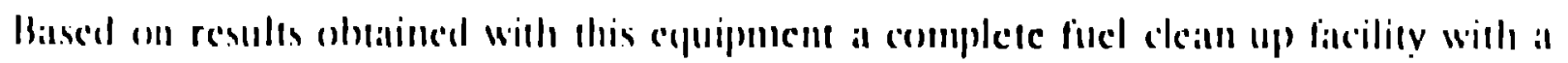


throuput of 1/5 ITER has been developed and designed by JAERI. The facility was instailed in TSTA in early 1990 and is now being tested under cold conditions.

According to another concept [29] the gas from the torus is first submitted to a pretreatment, i.e. catalytic conversion of oxygen into water and removal of this species by condensation, to preclude the formation of nitrogen oxides. The "unburned" fuel is then extracted at a pressure of 2 bar with a permeator operated at $573 \mathrm{~K}$. The bleed flow from the permeator is reduced to atmospheric pressure and passed through a nickel catalyst reactor for the cracking of ammonia. The hydrogen carried over with the impurities is oxidized cat lytically mainly to protect the down stream ratalyst (avoidance if hot spots) used for the oxidation of lydrocarbons. The oxidation of the hydrusarbons up to a conversion of $90 \%$ occurs on an alumina supported palladium catalyst at $573 \mathrm{~K}$. All oxidation reactions require the supply of an oxygen siream. The large number of single steps sofisticated contro! instrumentation mandatory. Ali. water produced is collected by gravity and decomposed by electrolysis.

\section{Isutope separation}

The isotope separation system (ISS) separates molecular hydrogen isotopes into an enriched tritium stream for fuel preparation, a detritiated deuterium stream for recycling into the neutral beam injector and fucl preparation, and a detritiatcd hydrogen stream for pellet injector propellant or discharge into the environment.

\subsection{Process requirements}

li) meet single event releatse constraints the ISS must be designed to have less thatl a given limited tritium inventory (for l'Tl:k the max. inventory shall be limited (o) 2(10) p). Normally the ISS will operate at pressures slightly above atemospleric and will he connected (1) an expansion lank (1) maintain llic systems internal pressure all a reasonable level in case of loss of conling [.3]. 


\subsubsection{Isotope separation by distillation}

Cryogenic distillation using isotope hydrogens including up to $1.5 \mathrm{~g}$ of tritium have been carried out with two columns of different diameter and packing size [30]. HETP values (Height Equivalent io a Theoretical Plate) were correlated with the feed flow rates and vapour streams of the column as well as with the reflux ratio.

The ISS at TSTA has been operated for an extended period of time with a tritium inventory of approx. $100 \mathrm{~g}$. Recently, the operation of two cryogenic columns with D-T mixtures and of four cryogenic columns with D-T mixtures containing impuritics such as $\mathrm{He}$ and $\mathrm{H}_{2}$ was investigated [31]. Observed and calculated mole fractions showed good agreement except for the concentration of HT and DT, which were found to be higher than the calculated values. IIETP values of $4.5-6 \mathrm{~cm}$ were obtained independent of vapor velocities, when varied in the range $4-14 \mathrm{~cm} / \mathrm{s}$. The results lead to the conclusion that a helium concentration of $27 \%$ is still acceptable for a normal operation of the columns.

Large cryogenic distillation columns have been operaied succesfully at Ontario I lydro's Darlington Tritium Removal Facility. Integrated operation has been demonstrated and over 2500$) \mathrm{g}$ of $>99$. \% trit i'ın gas has been extracted from $\mathrm{D}_{2} \mathrm{O}$ containing (5.6 - 7.4) $\mathrm{x}$ $1011 \mathrm{Bu} / \mathrm{kg}$.

\subsubsection{Isofope scparation by gats chromanography}

lior the separation of isotope hydrogens a displacement gas chromatograph |.32| with a lhroly phput of 20 mol/d, having four columus, cach containing 5 I of a packing consisting "If pallialium on alumina has been installed at Ji:T. 'The method is based on the strong istinge effect of the P(J) (1) . = II, I), T) system in the $H$-phase region of the phase diagramm. ( als chromatlography will he used in Jl:l' when the torus is operated will lwo)

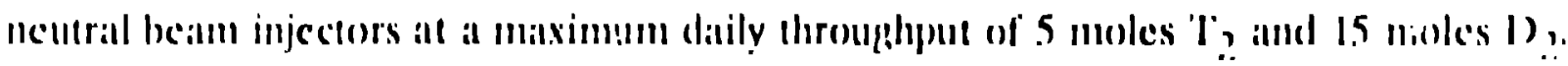
Displacement gits chromatopgraphy hats been succesfully demonstrated in extended us: with largec amounts of tritium |3.3|. 
A conceptual design description for an integrated ISS for ITER based on the requirements ior a) plasmal exhaust gas processing $(71.4 \mathrm{~mol} / \mathrm{h}$ with $1 \% \mathrm{HI}, 49.5 \mathrm{c} c \mathrm{D}$ and $49.5 \%$ ' $\mathrm{T}$; in case of iIITEX clean up $457 \mathrm{~mol} / \mathrm{h}$ with $99.564 \% \mathrm{H}, 0.216 \% \mathrm{D}$ and $0.218 \% \mathrm{~T}), \mathrm{b})$ neutral beam injection deuterium clean up (378 mol$/ \mathrm{h}$ with $0.03 \% \mathrm{H}$, 98.47\% D and $1.5 \% \mathrm{~T})$, waste water detritiation $(200 \mathrm{~kg} / \mathrm{h}$ with $0.1 \mathrm{Ci} / \mathrm{kg})$ and tritium recovery from a solid breeder blanket ( $105 \mathrm{~mol} / \mathrm{h}$ with $99 \% \mathrm{H}$ and $1 \% \mathrm{~T}$ ) has been Jeveloped in a collabosation between CFFTP, Ontario Hydro (FLOWSHEFT process simulator), the NET/ITER teams, and TSTA (dynamic cryogenic distillation code). The ISS products are detritiated water (with less than $1 \mathrm{lCi} / \mathrm{kg}$ of tritium), a protium stream (with a tritium atom fraction of $<10^{-9}$ ), a deuterium stream (with less than $10^{-7}$ of $\mathrm{T}$ and $0.2 \% \mathrm{H}$ ), and a tritium stream (with $80 \%$ T, $20 \% \mathrm{D}$ and less than $10 \mathrm{ppm} \mathrm{H}$ ).

The ISS comprises a waste walter detritiation front-end and a cryogenic distillation. Two water detritiation options were considered, i.e. water distillation or CECE (combination of two liçuid phase catalytic exchange columns with an electrolyser).

The components comprising the ISS are the most complex and expensive of all tritimu processing systems.

\section{5. 'Iritium storuge}

\section{1. l'rocess repuirements}

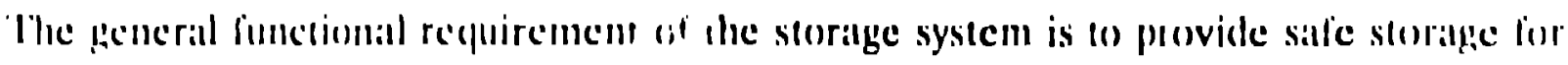
all hydrogen isotopes during starem, runilown, and shuedown operations under mormal and abmormal conditions 1.359. Fuel storage has to sattisfy the following functional

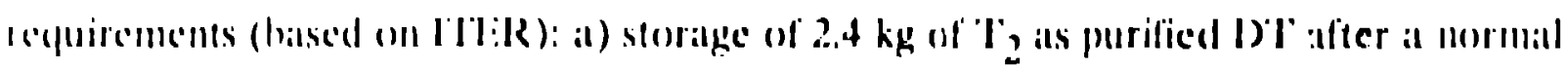

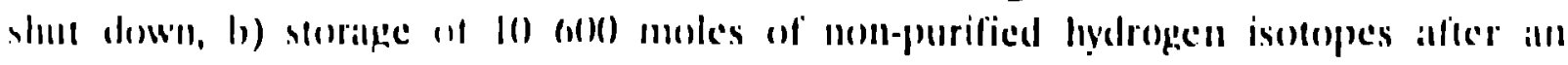

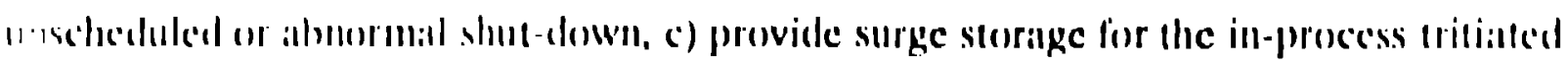

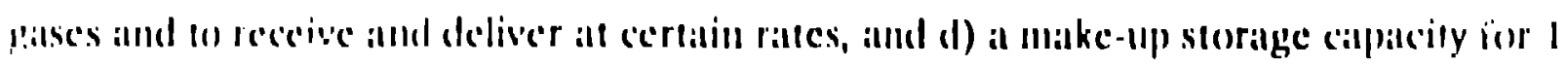

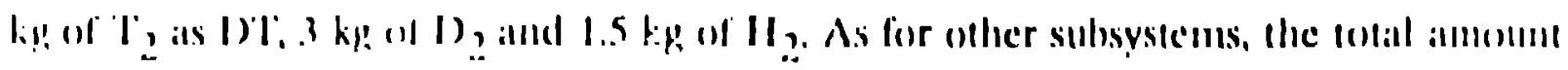

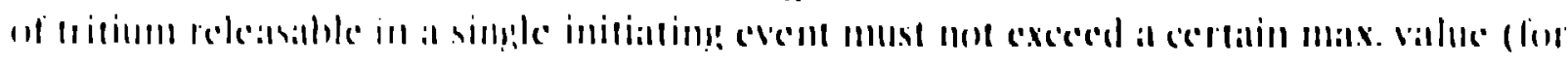
I I R R . (1) . (1). 
Hydrogen isotopes maly be stored in buffer tanks or as hydride (or deuteride or tritide) of metals or metal alloys.

\subsubsection{Properties of uranitm tritide and of alternative tritide forming intermetallics}

Uranium hydride has been extensively studied in view of its use as hydrogen storage system and been amply demonstrated for the storage of tritium. In the JET Active Gas I Iandling System 16 uranium beds will be employed, 12 (for storage of isotope mixtures and pure $\mathrm{D}_{2}$ ) contain 18 mols each of depleted activated U-238 (max. storage capacity 27 moles $c_{2}^{n}$ hydrogen per bed) and 4 (for storage of pure $T_{2}$ ) contain 5 moles each of $(T$. 238, giving a max. storage capacity of 7.5 moles $T 2$ per bed. Activated uranium is a fine powder, which reacts exuthermically with oxygen to form uranium oxydes (ca. 850 $\mathrm{kJ} / \mathrm{mol} \mathrm{O}_{2}$ ) and with nitrogen to form uranium nitrides (ca. $600 \mathrm{~kJ} / \mathrm{mol} \mathrm{N}_{2}$ ). To assess silfety hazards for the highly unlikely case of air ingress, only possible in case of multiple faults, a fully activated uranium bed was exposed to ambient air under controlled conditions [36]. The results indicate that not more than 30 barl of air are absorbed by the bed, the temperature increasing to only ca. $413 \mathrm{~K}$. The reaction does not proceed (o) completion because of surface passivation and, to some extent, because of a blanketing cifect caused by the continuous argon partial pressure increase in the vessel (the mol fraction \% of argon in air is 0.93 ). Because less than $2 \%$ of the helium-3 produced during an aging pesiod of 280 days is re!etsed from stoichiometric uranium tritide (ihe release increnses dramatically aftenvards approaching the generation rate alfer alout 1000 (lays) a pressureless tritium storage is possible over an extended period of time |.37].

While uranium has been demonstrated as a tritium storage miterial there is continnin!! interest in the development of alternative gelters hiving less chemical reatctivity towards air and other gasses and no legal restrictions due su nuclear character.

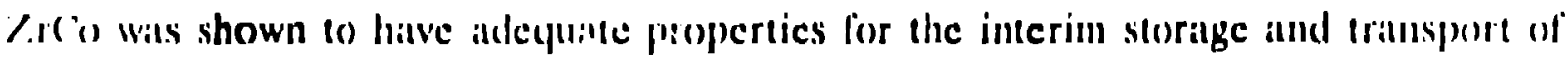
tritum [34, 39|. This intemetallic compound/hydrogen isotope system has hecu

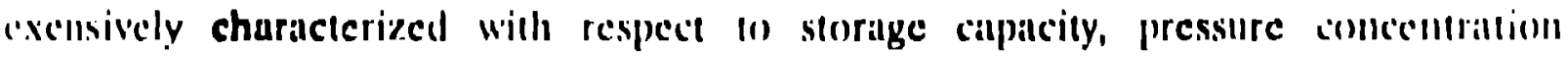

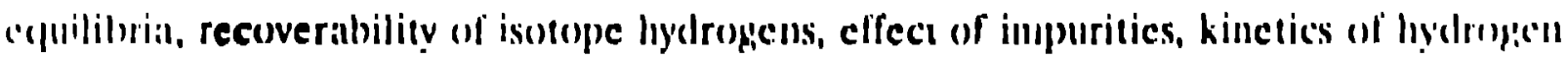

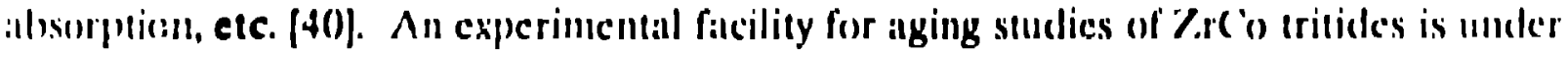

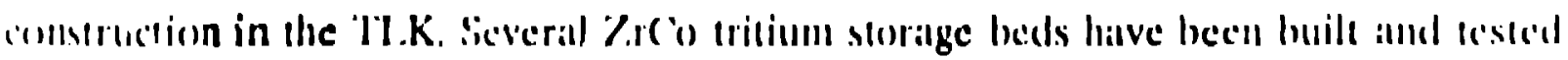

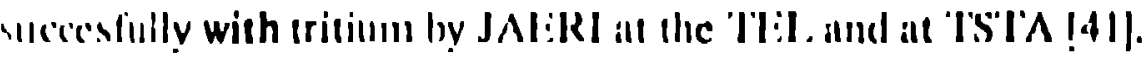


In view of screening tests to select the most adequate material for tritium storage with several $\mathrm{LaNi}_{5-\mathrm{x}} \mathrm{Mn}_{\mathrm{x}} \mathrm{H}_{\mathrm{y}}(0.5<\mathrm{x}<2)$ alloys, that indicated that the lowest equilibrium pressure is obtained for $x=2$, the pressure-composition isotherms for the systems $\mathrm{LaNi}{ }_{3} \mathrm{Mn}_{2}-\mathrm{II}_{2}, \mathrm{LuNi}_{3} \mathrm{Mn}_{2}-\mathrm{D}_{2}$, and $\mathrm{LaNi}_{3} \mathrm{Mn}_{2}-\mathrm{T}_{2}$ were determined [42]. Another selection criterion is the loading capacity at a given pressure, which was shown to decrease with increasing $x$ [33]. Work at Bruyères-le-Chatel therefore concentrat:sd on $\mathrm{L}_{\mathrm{aNi}} \mathrm{Ni}_{5-\mathrm{x}} \mathrm{M} \mathrm{n}_{\mathrm{x}}$ for $0.5<\mathrm{x}<1.5$. Experiments were carried out to investigate the kinetics with hydrogen isotopes as a function of grain size, the blanketing effect, and the thermal (onductivity as a function of stoichiometry. Aging studies at room temperature covering a period of one year revealed that less than $1 \%$ of the decay helium is releused during this time.

\subsection{2. 'lechnical storage vessels and storage facilities}

The concept design and construction of a storage unit comprising five storage modules in a double containme't for storing up to $100 \mathrm{~g}$ of tritium (DT equinolar form) has been (onpleted and installed in a glove box at Bruydres-le-Chatel $[20,33]$. According to this concept the five storage modules are connected to a central thermal exchanger. The compound used for tritium storage is placed inside of the module in a porous containment of conical configuration. Testing of the facility is scheduled for 100$) 1$.

Based on the getter material preselected by the ITT:R liucl (Yycle deigin tean, i.c. Z.r( 'o, and the given process requirements a conceptual design description for a fuel Storage Syistem and the corresponding liucl Maniggement System was developed [4.3]. According

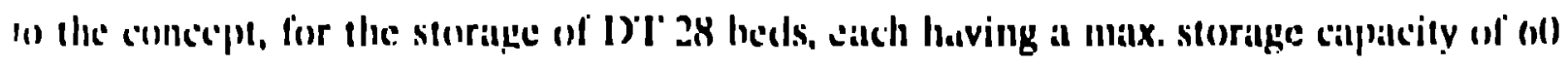
mols of hỵdrogen isotopes, and for the storage of $I_{2} / I_{2}$, is he:ls cath having a max.

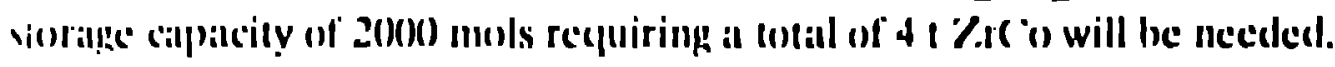

\section{b. 'Iritium coxtruction from a blunket}

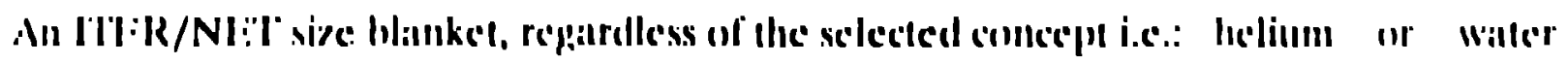

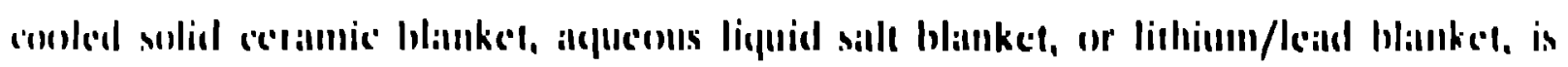

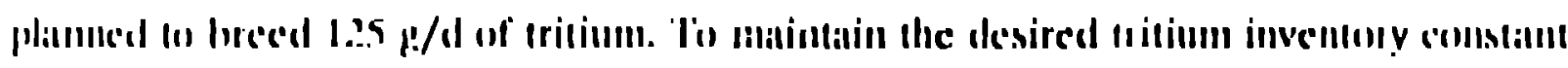

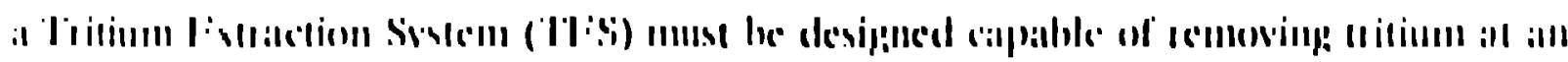

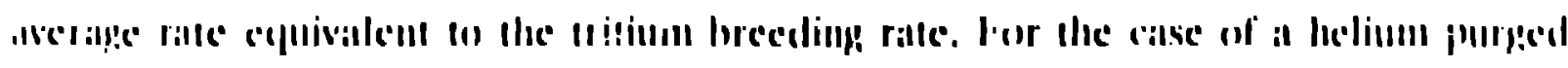

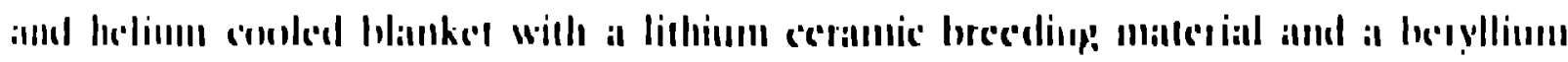


multiplier tritium is also bred within the beryllium zone, i.e. $1.52 \mathrm{~g} / \mathrm{d}$, of which a fraction of $14 \%$ is reicused. Therefore an additional purging system must be included if the bryllium zone is physically separated from the lithium ceramic zone.

Sume basic design requirements concerning the purge gases of the lithium ceramic zone and (eventually) the beryllium zone have been compiled in Table II [44].

'The design requirements stipulate that the breeder material in the blanket is to be maintailied at temperatures in the range $723-873 \mathrm{~K}$ and shall be purged with helium at 1.5-2.3 bar, containing $0.1 \%$ hydrogen. The anticipated swamping ratio is $H / T=100$. The blanket tritium recovery system shall prorluce a stream of dry hydrogen with a dew point of $\mathrm{T}<173 \mathrm{~K}\left(<0.014 \mu\right.$ bar $\left.\mathrm{H}_{2} \mathrm{O}\right)$ and contain less than 1 ppm total impurities, so that it can be fed directly into the Isotope Separation System.

In this. paper only TES's proposed foi solid ceranic blankets will be discussed.

\subsubsection{Cryoadsorption/Permeation/Lilestrolysis Concept $[45,46]$}

(Jne water coole: ceramic blanket option presently under discussion consists of water/beryllium/lithium zones paralell to the first wall, which are isolated from each oller by stainless stecl clads. According to this option, water in-leakage is only possible into the beryllium anne, hecause only this zone is immediately adjacent to the coobling witter zonc.

Inder the assum!nion, that most of the tritium in the purge gas is in the molecular hỵdrogen form, a tritium exeraction process concept based essentially on cryosonption, permeation, and water electrolysis has been developed. In a first secp water

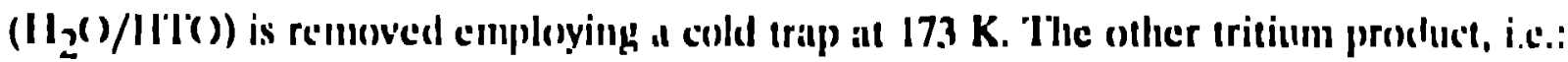
$\mathrm{II}_{2} / \mathrm{HT}$; is sepatrated firm the helium purge gas logether with all other tritiated antel

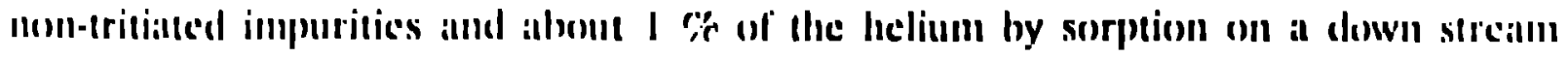
placed mulecular sicie hed coulsel fo licpuid nitrogen temperature (77 K).

The molcoular sieve hed meeds to he regenerated periodically. This is carried ont

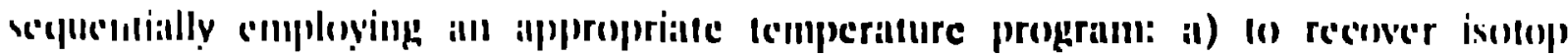

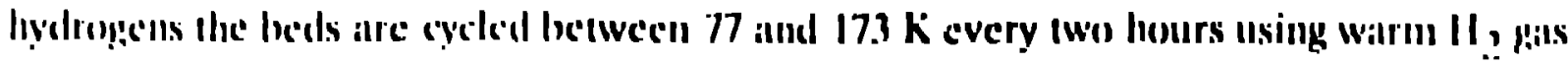

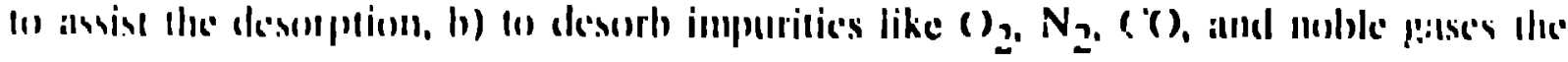

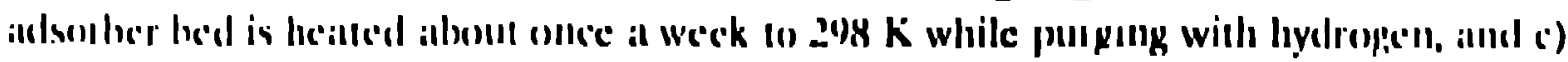

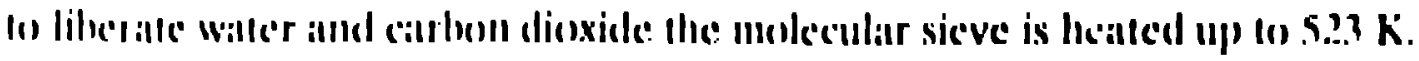


Table II Process requirements: Composition, tlows, and other parameters of the purge givs through the lithium ceramic zone and the buryllium zone of a solid breeder blanket [+5].

Ceramic blanket purge gas

inlet outlet

Cemperature $\mathbf{K}$

723-873

723-873

Pressure [har]

$1.5-2.3$

1.2

Ile flow $[\mathrm{kmol} / \mathrm{d}]$

2815

2815

(2) flow [kmol/d]"

2.815

2.815

$\mathrm{O}_{2} \mathrm{O}$ llow [mol/d]

2.818

28.01

Total inpurities [mol/d]

0.120

1.20

Tistal tritium flow $[\mathrm{kCi} / \mathrm{d}]$

166.2

1655

Bernyllium zone purge gas

inlet

outlet

Temperature $\ddot{i}$

723

723

Pressure |har|

1.5-2.3

1.2

Ile Heov [kmol/d]

3.24

3.24

1) 2 llow [mol/d]

0.0532

(0.532

(2), () llow [mol/d]

0.00 .324

555.6

lintal impuritics [mol/s!)

(0.) $00 \times 170$

(1). $(2499$

intal tritium thew [(':/d]

3.988

3247.2

(1) Till

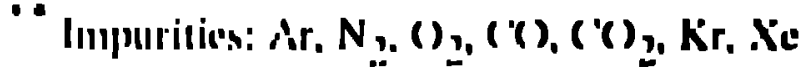

The isotenp hydrogens recovered from the molecular sieve bed in high concentration are

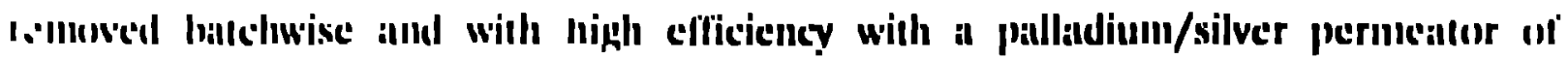

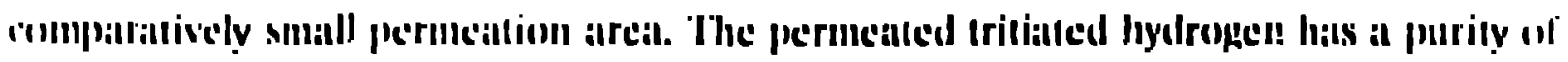
(1). (1) 
To prevent that impurities arising from a possible leakage through one 0 : the permeation tubes clog the cryogenic isotope separation system, a lot metal giard getter bed is installed between the permeator and the cryogenic columns.

Inpurities, inclıding those containing tritium, are sent to an interfacing impurity processing system. Water collected in the cooler is recovered periodically and decomposed into the elements hydrogen and oxygen using an electrolysis cell (options: wat electrolysis cell, solid polymer cell or high temperature solid oxide cell). While the electrolytical hydrogen is recycled into the TES, the oxygen is sent to the waste detritiation system.

Tritiated water p!oduced from the oxidation of impuritics such as ammonia and/or hydrocarbons in the waste disposal systen' is processed electrolytically together with the water collected in the cold trap.

Basically the same process steps as einploysu for the extraction of tritium from the blanket are used (o) extract (ritium from the beryllium zones. The only important Jifference is that iti this loop a larger electrolyris cell capacity is available to cope with possible water in-leakuges.

\subsection{2. l'reezer/Aúsurption l'rucess Concept [47]}

T'his concept assumes no plyssical separation between the breeder zone alld the heryllium zone. 'The purge heli. ' n from the breeder $\left(2.410^{5}-3.610^{5} \mathrm{~mol} / \mathrm{d}\right)$ comtaining Iritium as tritiated water and iritiated hydrogen is first cooled down by counter current I0 rom temperature aind the'l compressed to lo bar. A process pressure of I0 har is l.ied (o) (up!imize tle freexing (operations and to reduce the size of the components.

Afer removal of the compression heal the gas is passed through a prefreezer, in which essentially all the walcer is frozen ont. "The water partial pressure is further reduced dow'n

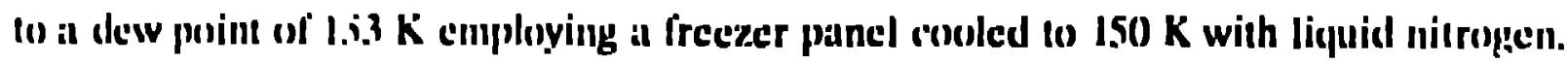

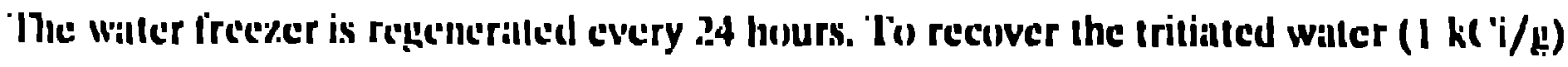
in the prefreczer panels, lle pancls are warmed up and the vaporized gases sint via a depatssing columm into an electrolyser. Ilydrogen and oxygen produced from llac electrolysis of water (albeut 2I mol/d throughput) are directly relurned into the le(t) antel

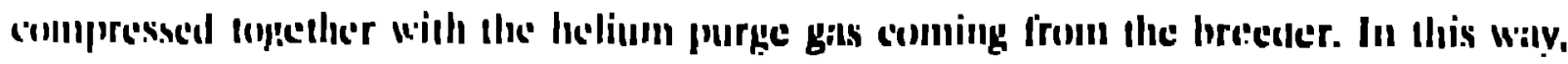
dlyying of heoth gatse's is cilcomvented and oxygen is removed tongether with the oflacr

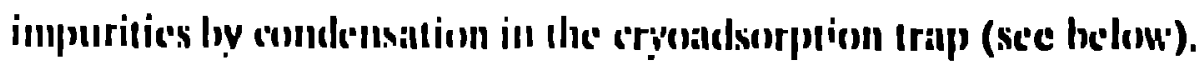


Low boiling gases, such as $\mathrm{N}_{2}, \mathrm{O}_{2}, \mathrm{CO}, \mathrm{CO}_{2}, \mathrm{CH}_{4}$, and residual $\mathrm{H}_{2} \mathrm{O}$, present as impurities in the purge gas (total impurities < $1.2 \mathrm{~mol} / \mathrm{d}$ ) are removed by adsorption at liquid nitrogen tenuperature $(75 \mathrm{~K})$. Regeneration of the adsorbers is carried out every iwo weeks at $423-473 \mathrm{~K}$.

Iydrogen $(22.8 \mathrm{~mol} / \mathrm{h})$ is separated from the purge gas helium in a freezer panel cooled to $\mathrm{T}<10 \mathrm{~K}$ with liquid helium. The clean purge gas is returned through several counter current heat exchangers to the breeder. The hydrogen recovered from the freezer, which contains only helium as a minor impurity, can be fed direstly into the isotope separation system.

\subsubsection{Tritium extraction system for a NET blanket test plug [48]}

According to the TES proposed for the NET heliutn cooled solid breeder blanket test plug the helium off-gas $(6.5 \mathrm{~mol} / \mathrm{d}$ with a total pressure of approx. $1 \mathrm{oar}$, containing 0.1 vol. \% $\mathrm{H}_{7}$ ) carries tritiated hydrogen and water. $\mathrm{H}_{2} \mathrm{O} / \mathrm{HTO}$ is remeved in a large 31.6 $\mathrm{kg} 3 \Lambda$ molecular sieve . Jsorbur bed held at $\mathrm{T}<313 \mathrm{~K}$ (max. sorption capacity at PHTO $=0.133 \mathrm{~Pa}$ is $0.02 \mathrm{gHTO} / \mathrm{g}_{\mathrm{MS}}$, which gives rise to a regeneration time $=1 \mathrm{a}$ ). After the removal of water the $\mathrm{He}$ is recirculated through a palladium/silver permeator of $6.3 \mathrm{~m}^{2}$ total permeation area, which reduces the partial pressure of hydrogen from $100 \mathrm{~Pa}$ down to $1 \mathrm{~Pa}$. Thr permeated hydrogen isotopes are collected as metal hydrides in a getter bed containing uranium (regeneration period of the getter bed $=4.2 \mathrm{~d}$ ). The loop on the secondary side of the permeator contains helium recirculated with an oil-free pump.

Impuritics in the helium purge gas, in particular nitrogen, are removed by adsorption on $3.3 .1 \mathrm{~kg}$ charcoal cooled down (o) $96 \mathrm{~K}$ (loading calpacity at $\mathrm{P}_{\mathrm{N} 2}=0.1 \mathrm{~Pa}$ is $0.02 \mathrm{~g}_{\mathrm{N} 2} / \mathrm{g}_{(}$? regencration period $=1 \mathrm{a}$ ).

\section{Conclusions}

Batsed on lahoratory and lechnical sc:ale experiments feasible design concepts have been developed for all fusion reictor fucl cycle subsystems. Further work is needed of "pptimize single process steps and to demonstrate the operation of integral facilities. ()f crucial importance are steps towards further reduction of the tritium inventory in the various subsystems. Rescarch atclivities in the future should concentrale on the 
demontration with relevant amounts of tritium of the safe and reliable operation of prototype components and prototype facilities.

\section{Acknowledgements}

We gratetully thank H.R.Ih'e for many valuaiole comments.

\section{Literature}

[1] M.A.Abdou, E.L.Vold, C.Y.Gung, M.Z.Youssef, K.Shin, Deuterium-Tritium Fuel Self-sutficiency in Fusion Reactors, Fusion Technol. 9 (1986) 250-285.

[2] F.Curré, E.Proust, A.Rocuboy, Analysis of the Tritium Requirements for a Power Reacior, Nuclear Technol./Fusion 4 (1983) 93-98.

[3] D.Leger, P.Dinner, M.Yoshida, R.Fleıning, J.Anderson, A.Andreev, M.Asahara, J.C.Boissin, P.Finn, M.Gouge, M.Iscli, V.Kapaishev, S.Kobaashi, B.Kuteev, O.Kveton, M.Muller, D.Murdoch, K.Nagashima, J.Nasize, R.-D.Penzhorn, D.V. Serebrennikov, G.Shatalov, R.Sherman, T.Suzuki, D.Sze, N.Taneınori, V.Vasil'ev, S.Willms, ITER Fuel Cycle, I1ER Documentation Scrics No.31 IAEA, Vienna, (1991) 1-212.

[4] J.I.ILemmerich, The Cryogenic Diffusion Pump - an Advanced Design for liusion Reaclor Prinlary Pumping and IFuel Processing, Fourth Topical Mceting on Tritium Technol. in Fission, Fusion and Isotopic Applications, Albuquerque, Scpt. 30 - ()it. I $(1991)$ (1) appear.

[5] U.Bkerndt, T.L.L.e, I:.Kirstc, M.Glugla, R.-D.Penzhorn, Performance Characteristics (1) I.arge Scroll l'umps, Second Int. Symp. leusion Nucl. Technol, Karlsruhe (1991) (1) appeir.

[(o] I).Murdoch, J.-C', IBoissin, A.C 'onrad, D.Perinic, Forepumping Concept for NI:T' Torus lixhaust, loth Symp. un liusion Fechunl, Iondon, Sept. 3-7 (1990) to appear.

17] 'I.I layasshi, S.Konislii, M.Yamada, Y.Matsuda, M.Inouc, T.Nakamura, T.'Takanąă, Y.Narusc. K.()kuyama, 1)evelopment of a I arge ()il-free Koughing Pump for 'Tritium 
Service, 9th Topical Meeting on the Technol. of Fusion Energy, Oak Bruok, Ill. Oct. 7. 11 (1990) to appear.

[s] C.Gordon, Joint European Torus Active Gas Handling System, JET-TN(88)02 (1988) 1-106.

[9] C.R.Walthers, D.W.Sedgley, T.H.Batzer, D.Lang, D. Hathaway, H.Fukai, K.Okuno, N.Enoeda, T.Ide, Y.Naruse, Co-pumping of Deuterium-Helium and Tritium-Helium Mixtures at TSTA, Proc. of IEEE 13th Symp. Fusion Eng., Knoxville, Oct. 2-6 (1989) 959-962.

[10] C.R.Walthers, E.M.Jenkins, D.W.Sedgley, T.H.Batzer, S. Konoshi, S.O'Hira, Y.Naruse, Continued Studies of Co-pumping of Deuterium and Helium on a Single, $4 \mathrm{~K}$ Activated Charcoal Panel, to appear.

[11] H.Huas, A.Mack, D.Perinic, Experimental Investigation on Helium Cryosorption of Porous Solids, 16th Symp. on Fusion Technol., London, Sept. 3-7 (1990) to appear.

[12] H.Yoshida, S.Shibanuma, Progress on Japanese Large Magnetic Bearing Type Turbomolecular Pump Development, Iter Fuel Cycle Experts Meeting Aug. 21-31 (1990).

[13] M.Glugla, R.-D.Penzhorn, R.Rodriguez, D.Herbrechter, P.Dininer, D.Murdoch, Evaluation of concepts for a NET Plasma Exhaust Clean-up System, KtK-Report 4752 $(199()) 1-118$.

[1+] S.Konishi, M.Inouc, T.Hayashi, K.Okuno, Y.Naruse, J.W.Barnes, J.L.Anderson, Development of the JAERI Fuel Clean Up System for Tests at the Tritium Systems Test Assembly, 9th Topical Meeting on the Terhnol. of Fusion Energy, Oak Brook, Oct.7-11 $(199())$ to appear.

[15] P.Giroux, T.Pelletier, P.Boucquey, J.F.Bressicux, Palladium/Silver Membrane Diffusion of I lydrogen Isotopes: Gas Purifying Furnace, CEA, Centre d'Etudes de Valduc, P'rrgesess Report ( IU90) 1-20.

|lo| R.-1).Penzhorn, The PIITRA Experimennt: Description and Safety Assessment of a l.ong-term P'ermeatur Perturmance 'lest, (o) alppear.

|17| P.Giroux, 'T.Pelletier, P.Buncquey, J.Bressicux, IElectrolysis cell for Ilighly 'Jritiated 
Water, 16th Symp. on Fusion Technol. Sept. 3-7, (1990) to appear.

[18] A.Bruggeman, A.Rahier, R.Cornelissen, J.M.Miller, R.E.Johnson, R.J.Keyes, Testing of a Capillary Electrolysis System for Highly Tritiated Water, 16th Symp. Fusion Technol. London, Sept. 3-7 (1990) to appear.

[19] J.L.Hemmerich, A.Dombra, C.Gordon, E.Groskopfes, A.Konstantellos, The Impurity Processing Loop for the JET Active Gas Handling System, Fusion Technol. 14 (1988) 557-561.

[20] B.Hircq, Tritium Tasks for the NET Fusion Technology Program, Report CEA-N2644, Oct. (1990) 1-288.

[21] U.Tamm, E.Hutter, G.Neffe, Experiments on the Development of the Tritium Clean-up System by the Getter Method for Use in The Tritium Laboratory Karlsruhe, 16th Symp. Fusion Technol., London, Sept. 3-7 (1990) to appear.

[22] H.Albrecht, U.Kuhnes, W.Asel, Application of SAES and HWT Gas Purifiers for the Removal of Impurities from Helium/Hydrogen Gas Mixtures, Int. Symp. Metal Hydrogen Systems, Fundamentals and Applications, Banff, Sept. 2-7 (1990) to appear.

[23] R.S.Willms, Fusion Fuel Purification during the Tritium Systems Test Assembly 3Week Loop Experiment, 13th IEEE Symp. on Fusion Energy, Knoxville, Oct. 2-6 (1989) to appear.

[24] R.-D.Penzhorn, H.E.Noppel, to appear.

[25] M.Glugla, R.-D.Penzhorn, R.Rodriguez, D.Herbrechter, Design of a Citalytic Plisma Exhaust Gas Clean-up Facility for NET II, Final Report 322/88-8/FU-D (NETNo 88-173) (1990) 1-130.

[?(6] M.Glugli, R.-D.Penzhorn, J.L.Anderson, J.R.Bartlit, R.S.Willuns, Tritium I:xperiments with a Catalytic Fucl Clean Up Loop, Tritum Technol. Fission, Fusion, Isotope Apllications, Albuquerque, (1991) to appear.

[27] A.Busigin, K.B.Woodall, S.K.Sood, K.M.Kalyznan, A High Tesnperature Isotopic I:xelbiuge Proncess For Recovering Tritium from Fusion liucl Impuritics, Second In'. Symp. Fusion Nucl. Technol., Karlsruhe (1991) to appear. 
[28] S.Konishi, S.O'Hira, F.Sakui, T.Yamanishi, K.Okuno, Y.Neruse, Experiments on the Fusion Fuel Processing at the Tritium Process Laboratory, 13th IEEE Symp. on Fusion Energy, Knoxville, Oct. 2-6 (1989) 626-629.

[29] D.Leger, D.Mrrijuci, B.Hircq, D.Latge, A Conceptual Design for the NET II/ITER Fuel Clean-up System, 16th Symp. Fusion Technol., London, Sept. 3-7 (1990) to appear.

[30] T.Yamanishi, M.Enoeda, K.Okuno, T.Hayashi, J.Amano, Y.Naruse, R.H.Sherman, Experimental Study for Separation Characteristics of Cryogenic Distillation Columns with H-D-T- System, 9th Topical Mecting on the Technol. of Fusion Energy, Oak Brook, Oct.7-11 (1990) to appear.

[31] M.Enoeda, H.Fukui, T.Ide, K.Okuno, Y.Naruse, J.L.Anderson, J.R.Bartlit, R.H.Sherman, R.S.Willms, Separation of Helium and Hydrogen Isotopes by ISS at TSTA, 13̄th IEEE Sỵmp. on Fusion Energy, Knoxville, Oct. 2-6 (1989) 630-633.

[32] F.Botter, J.Gowman, J.L.Hemmerich, B.Hircq, R.Lässer, D.Leger, S.Tistchenko, M.Tschudin, The Gas Chromatographic Isotope Separation System for the JET Active Gas Handling Plant, Fusion Technol. 14 (1988) 562-566.

[33] B.Hircq, Tritium Activities for Fusion Technology in Bruyères-le-Chatel Center CEA France, Fusion Technol. 1+ (1988) 424-428.

[34] A.Busigin, S.K.Sı,od. O.K.Kveton, R.H.Sherman,J.L.Anderson, ITER Isotop) Separation System Conceptual Design Description, Revision 2.0, June 5 (1990) (1) appear.

[35] D.Leger, Tritiuun System: (ieneral Process Description for Design Integration, [TER-FC-1.1-()-20. (1990) 1-42.

[36] J.L.L1:-mmerich, Air Lxpmsure Test of a Jl:T AGISS Uranium Hed, JI:I Re'pul, Aug. (1990) 1-8

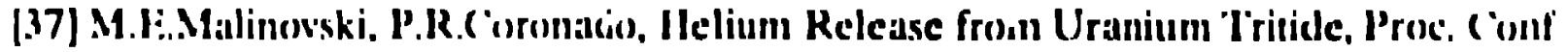

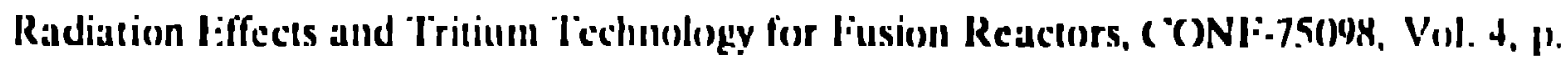
$5.67(1975)$.

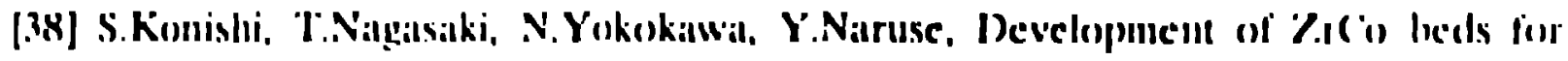


Recovery, Storage and Supply of Tritium, Fusion Eng. Design 10 (1989) 355-358.

[39] R.-D.Penzhorn, M.Devillers, M.Sirch, Evaluation of ZrCo and other Getters for Tritium Handling, and Storage, J.Nucl. Mater. 170 (1990) 217-231.

[H()] M.Devillers, M.Sirch, S.Bredendiek-Kämper, R.-D.Penzhorn, Characterization of the $\mathrm{ZrCo-Hydrogen} \mathrm{System} \mathrm{in} \mathrm{View} \mathrm{of} \mathrm{its} \mathrm{Use} \mathrm{for} \mathrm{Tritiun} \mathrm{Storage,} \mathrm{Chem.} \mathrm{Materials} 2$ (1990) 255-262.

[+1] S.Konishi, H.Yoshida, Y.Naruse, R.V.Carlson, K.E.Binning, J.R.Bartlit, J.L.Andesson, Tritium Experiments on Components for Fusion Fuel Processing at the Tritium Systems Test Assembly, 9th Tcpical Meeting Technol. Fusion Energy Oak Brook, Oct. 7-11 (1990) to appear.

[42] T.Ide, K.Okuno, S.Konishi, F.Sakai, H.Fukui, M.Enoeda, Y.Naruse, J.L.Anderson, J.R.Bartlit. LaNi3Mn2 Alloy as a 'Tritium Storage Material, 13th IEEE Symp. on l'usion Energy, Knoxville, Oct. 2-6 (1989) 616-619.

[4.3] J.Nasise, M.E.Muller, J.L.Anderson, J.R.Bartlit, ITER Fuel Storage System Conceptual Design Description, to appear.

[H] M.ISELI, Design Requirements: Tritium Recovery from The Purge Gus of the Wuter Cionled (cramic Blanket, ITERR Fuel Cycle Experts Meeting Aug. (1990) (1) alppeir.

[4.5] P.A.IINN, I).K.S\%.I:. R.(i.CI.I:MMI:R, Conceptual Design Description for the Tritium Recovery System tor the U.S. I'TI:R I. $\mathrm{i}_{2} \mathrm{O} / \mathrm{Be}$ Water Cooled Blanket. ANI./HPP/TM-2.+4 (I9)(1) t(1) alpluear.

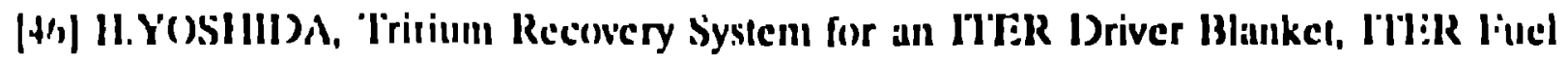
(yele lixperts Mecting., (iarching, Aug. (1089) (1) alppear.

|47| M.ISI:I I, M.SC IIAIIB, ZII:R ('cramic Brecder Blanket T'ritium Recovery System,

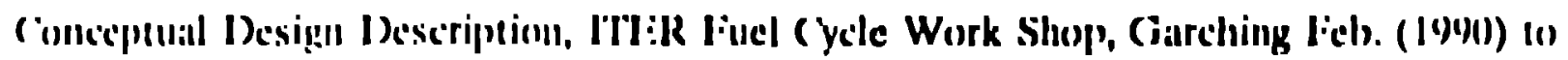
iाploir.

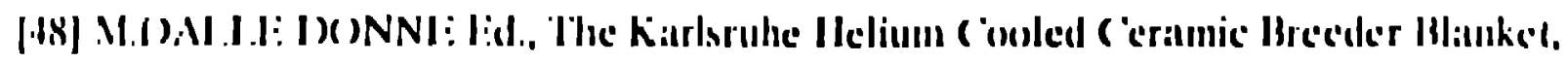
Kik (I)(I)) (1) : ilpurar. 